\title{
Performance Analysis of Different Grid-Connected PV technologies under Fez weather conditions
}

\author{
Mourad Benfares ${ }^{1, *}$, Izeddine Zorkani ${ }^{1}$, Ali Didi Seddik ${ }^{1}$, Anouar Jorio ${ }^{1}$, Mohammed El Ganaoui ${ }^{2}$ \\ ${ }^{1}$ LPS, Physics Department Faculty of Sciences Dhar Mehraz (FSDM), Sidi Mohammed Benabdellah University Fez, Morocco \\ ${ }^{2}$ LERMAB, IUT de Longwy, Université de Lorraine 186, rue de Lorraine. F-54400 Cosnes et Romain, France
}

\begin{abstract}
The main objective of this study is to compare the one-year performance of $5.94 \mathrm{KWp}$ gridconnected PV array systems, consisting of three types of mono-Si $(2.04 \mathrm{KWp})$, poly-Si $(2,04 \mathrm{KWp})$ and a-Si $(1,86 \mathrm{KWp})$ photovoltaic solar panels, installed on the roof of the Faculty of Sciences Dhar El Mahraz in Fez. The study is based on data collected in 2017 on energy production. The performance elements evaluated monthly and annually include: energy output, system efficiency, reference yield, final yield, performance ratio, annual capacity factor. The results show that poly-Si technology has the best performance. A comparison between PV Production in different locations in the world and will presented, also we can conclude that Northern Morocco is a good region for PV production.
\end{abstract}

\section{INTRODUCTION}

Previously published studies show that the energy performance of PV modules depends on the climatic conditions (temperature, solar irradiation, etc...), and on the type of materials used in the production process, which determines the type of PV modules suitable for each the installation site. According to studies that in Morocco under the "propre.ma" project introduced in the framework of renewable energy launched by IRESEN. Amine Haibaoui et al [1], concluded that the mono-Si system has the best performance followed by poly-Si and a-Si. In addition, they established the relationship between efficiency and temperature, performance ratios and radiation, in order to know the behaviour of each technology for each period of the year and for the whole year. El Fathi et al [2], found a significant difference between the two technologies of (mono-Si and poly-Si) and amorphous. This difference is very important and that MPPT inverter is not well adapted to the I (V) curves of the amorphous silicon modules. Allouhi et al [3], found that the PV systems installed in Meknes have better performance indicators than those in other regions in Morocco. In another study, E. Başoğlu et al [4], presents an energy performance analysis of three different photovoltaic (PV) module technologies under İzmit, the weather conditions of Kocaeli in northwest Turkey. Benchmarking analyses were conducted to show the solar energy potential of İzmit, Kocaeli. The main objective of this study is to compare the performance of $5.94 \mathrm{KWp}$ grid-connected photovoltaic installations during one year, consisting of three types of photovoltaic solar panels: mono-Si (2.04KWp), poly-Si $(2.04 \mathrm{KWp})$ and a-Si (1.86 KWp) installed on the roof of the Faculty of Sciences Dhar El Mahraz in Fez Morocco. The study is based on data collected on the year 2017 on energy production. The performance elements evaluated monthly and annually include: energy production, system efficiency, benchmark performance, final performance, performance index, annual capacity factor. More by comparing the measured results with results found with previous studies in different locations.

This article is organized as follows. Section land 2 of this paper will focus on the location of the installation and the different behaviors of the PV system and the weather station, the definitions of the performance evaluation measures and their mathematical formulations. Section 3 is devoted to the analysis of the one-year performance of the grid-connected PV installation, consisting of three types of mono-Si poly-Si and a-Si PV panels installed, namely the energy production and performance indicators. Finally by conclusion which summarizes different results.

\section{EXPERIMENTAL SET-UP}

\subsection{Place of study}

The 5.94KWp grid-connected photovoltaic systems are installed on the roof of the Dhar El Mahraz Faculty of

\footnotetext{
* Corresponding author: mourad.benfares@usmba.ac.ma
} 
Science [FSDM] with a latitude of $34^{\circ} 2^{\prime} 0^{\prime \prime}$ North and a longitude of $4^{\circ} 58^{\prime} 36^{\prime \prime}$ West. Fez is a city in northern Morocco, located $180 \mathrm{~km}$ east of Rabat, between the Rif massif and the Middle Atlas. Being part of the imperial cities of Morocco with an area of about $424 \mathrm{~km} 2$, with a latitude of $34^{\circ} 03^{\prime} 00^{\prime \prime}$ North, a longitude of $4^{\circ} 58^{\prime} 59^{\prime \prime}$ West, and an altitude of $419 \mathrm{~m}$ at sea level.

\subsection{Grid-connected PV system}

The grid-connected photovoltaic system consists of 12 thin-film amorphous silicon (a-Si) panels, each with $155 \mathrm{Wp}, 8$ polycrystalline panels (poly-Si) and 8 monocrystalline panels (mc-Si), each with $255 \mathrm{Wp}$ [5]. The electrical and dimensional properties of these three PV modules are shown in Table 1. The A-Si modular series was installed in double row, while poly-Si and mono-Si in a single row. The PV modules are mounted to the south (Azimuth equal to 0 ) with a panel tilt angle of $31^{\circ}$, this value close to the optimal value to provide maximum annual efficiency. The position of this PV installation on the roof. Each modular series was connected to its specific Sunny Boy 2000 HF-30 inverter. All monthly or annual production information and the status of different PV system components are followed by software adapted to the inverters [5].

\subsection{Meteorological station}

In order to collect meteorological data, we have installed a meteorological station developed as part of the PROPRE.MA project [6], funded by the Institute for Research on Solar Energy and New Energies (IRESEN). This meteorological station measures horizontal and inclined solar irradiations at $31^{\circ}$, ambient temperature, wind speed and direction. Total irradiation is the measurement of the total amount of solar energy available for a PV system according to the location of the system and the direction of the modules, The solar collector used in our metrology system is a Poly-Si silicon module. [7]

The ambient temperature varies according to the medium, so that the measurements are valid, the sensor is in direct contact with the air, also protected from sun and rain. These temperature sensors are based on analog-todigital converters that convert the output signals of the sensors before being transmitted to the memory card in analog or digital form through different bus protocols. [8]
Table 1. Technical characteristics of PV modules.

\begin{tabular}{|l|c|c|c|}
\hline & Svstem-1 & System-2 & Svstem-3 \\
\hline Trademark & NexPower & \multicolumn{2}{|c|}{ SolarWorld } \\
\hline Model & $\begin{array}{c}\text { XTREM }+(\mathrm{NT}- \\
155 \mathrm{AF})\end{array}$ & $\begin{array}{c}\text { SUNMODULE plus } \\
\text { SW 255 poly }\end{array}$ & $\begin{array}{c}\text { SUNMODULE } \\
\text { Plus SW 255 mono }\end{array}$ \\
\hline Photovoltaic cell & Thin film (a-Si) & Poly crystalline & Mono crystalline \\
\hline Maximum p0wer at STC & $155 \mathrm{Wc}$ & $255 \mathrm{Wc}$ & $255 \mathrm{Wc}$ \\
\hline $\begin{array}{l}\text { Maximum power point voltage } \\
\text { (Vmp) }\end{array}$ & $65,9 \mathrm{~V}$ & $30,9 \mathrm{~V}$ & $31,4 \mathrm{~V}$ \\
\hline $\begin{array}{l}\text { Maximum power point current } \\
\text { (Imp) }\end{array}$ & $2,43 \mathrm{~A}$ & $8.32 \mathrm{~A}$ & $8.15 \mathrm{~A}$ \\
\hline Open circuit voltage (Voc) & $85.5 \mathrm{~V}$ & $38 \mathrm{~V}$ & $37.8 \mathrm{~V}$ \\
\hline Short circuit current (Isc) & $2.56 \mathrm{~A}$ & $8.88 \mathrm{~A}$ & $8.66 \mathrm{~A}$ \\
\hline Module Efficiency & $9,9 \%$ & $15,21 \%$ & $15,51 \%$ \\
\hline Length & $1412 \mathrm{~mm}$ & 1650 & $1675 \mathrm{~mm}$ \\
\hline Width & $1112 \mathrm{~mm}$ & $992 \mathrm{~mm}$ & $1001 \mathrm{~mm}$ \\
\hline Weight & $19.5 \mathrm{~kg}$ & $18 \mathrm{~kg}$ & $21.2 \mathrm{~kg}$ \\
\hline Temperature coefficient (Pmax) & $-0.28 \% /{ }^{\circ} \mathrm{C}$ & $-0.41 \%{ }^{\circ} \mathrm{C}$ & $-0.45 \% /{ }^{\circ} \mathrm{C}$ \\
\hline
\end{tabular}

\section{PARAMETERS EVALUATION OF THE PERFORMANCE SYSTEM}

Generally the conversion efficiency of PV systems is very low. As their available power depends on weather conditions such as solar radiation, temperature and other environmental conditions. Then the performance evaluation of PV modules becomes important. In order to study and evaluate the performance of the grid-connected photovoltaic installation, some indicators proposed by IEC 61724, NREL and SMA [9] can be used.

The electricity energy delivered to the grid is the energy delivered by the inverter in alternating current over a period of time, expressed in $\mathrm{kWh}$. [10]

$$
E_{A C}=\tau_{r} * \sum_{\tau} P_{A C}
$$

Where: $\mathrm{P}_{\mathrm{AC}}$ : The output power of the inverter. $\tau_{\mathrm{r}}$ : The time

The conversion efficiency or effectiveness to the STC, i.e. under a reference radiation quantity equal to $\mathrm{Go}=1 \mathrm{~kW} / \mathrm{m}^{2}$ at $\mathrm{T}=25^{\circ} \mathrm{C}$ and air mass $\mathrm{AM}=1.5$. [11]

$$
\eta_{S T C}=\frac{P_{S T C}}{G o * S_{m}}
$$

Where: $\mathrm{P}_{\mathrm{STC}}$ : Peak power of a PV panel (W) and $\mathrm{S}_{\mathrm{m}}$ : Effective area of the PV panel $\left(\mathrm{m}^{2}\right)$.

The overall efficiency of the system includes all losses caused by its components, from the modules to the point of injection of alternating current into the distribution network. [11]

$$
\eta_{s y s t}=\frac{E_{A C}}{E_{\text {sol }}}
$$

The photovoltaic field yield is defined as the ratio between the total energy produced $(\mathrm{kWh})$ by the PV panels for a defined period (day, month or year) and the $\mathrm{P}_{\text {ref }}$ nominal power $(\mathrm{kW})$ of the panels at the STC: [12]

$$
Y_{A}=\frac{E_{D C}}{P_{\text {ref }}}
$$


The final efficiency is the total energy produced by the PV installation, $\mathrm{E}_{\mathrm{AC}}(\mathrm{kWh})$ in relation to the $\mathrm{P}_{\text {ref }}$ installed nominal power $(\mathrm{kWp})$. [13]

$$
Y_{f}=\frac{E_{A C}}{P_{\text {ref }}}
$$

The reference efficiency is the ratio between the total solar radiation $\mathrm{H}_{\mathrm{t}}\left(\mathrm{kWh} / \mathrm{m}^{2}\right)$ on the surface of the $\mathrm{PV}$ solar panels and the reference amount of radiation Go $\left(1 \mathrm{~kW} / \mathrm{m}^{2}\right)$. [14]

$$
Y_{r}=\frac{H_{t}}{G o}
$$

The performance ratio is a key parameter used in the performance studies of grid-connected photovoltaic installations. [14-9] It is described as a quality factor, and describes the relationship between actual and theoretical production, during a reference period:

$$
P R=\frac{Y_{f}}{Y_{r}}
$$

The capacity factor compares the actual production of a PV installation with the energy it would produce if it operated at full capacity all the time. It measures the ratio between the energy actually produced by a photovoltaic installation during a period $(\mathrm{kWh})$ and the electricity it could have supplied by constantly operating at its peak power during the same period [10] :

$$
F C=\frac{E_{Y}}{P_{r e f} * \tau}
$$

Where : is the number of hours in the period considered (The period can be days, months or years).

\section{RESULTS AND DISCUSSION}

Analysis of the actual performance of the three silicon technologies (a-Si, mono-Si, poly-Si) connected to the network located at FSDM were performed using all the steps motioned in Part I. Graphs showing weather data, production and monthly average performance indicators of our systems were performed using measurements obtained 2017.

In order to study different irradiations and the choice of an ideal tilt angle. Figure 1 shows the monthly evolution of the solar radiation intensity on a south-facing plane with a fixed tilt angle of $31^{\circ}$. that the tilted irradiation is higher compared to the horizontal irradiation in this period.. The monthly average horizontal irradiation in January is the lowest compared to that of August, because the path of the sun. Thus, the inclination is intended to increase the irradiation received by the sensors during the winter period. For this purpose, the inclined irradiation will be used for performance analysis.

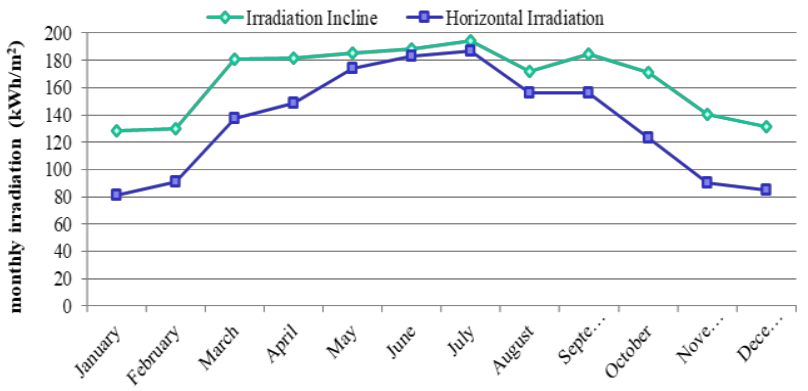

Fig 1. Monthly irradiation on a horizontal and inclined plane.

\subsection{Total $E_{A C}$ energy of the three PV systems}

The evolution of the monthly average AC energy per day (in $\mathrm{kWh} \mathrm{/} \mathrm{day)} \mathrm{generated} \mathrm{by} \mathrm{the} \mathrm{three} \mathrm{grid-connected} \mathrm{PV}$ systems (from January 2017 to December 2017), which AC energy is transferred to the utility is shown in Figure 2. Poly-Si silicon modules always give the highest AC power production. The months with the highest $\mathrm{AC}$ power production are the summer months. When the period of sunshine that is important in summer. A comparison of the annual energy production shows that the a-Si plant generated $3153.579 \mathrm{kWh}$, the second poly-Si plant generated $3558.975 \mathrm{kWh}$, and the third mono-Si plant generated $3476.866 \mathrm{kWh}$ per year. Consequently, the total energy produced by the three plants is approximately $10189.42 \mathrm{kWh}$ per year.

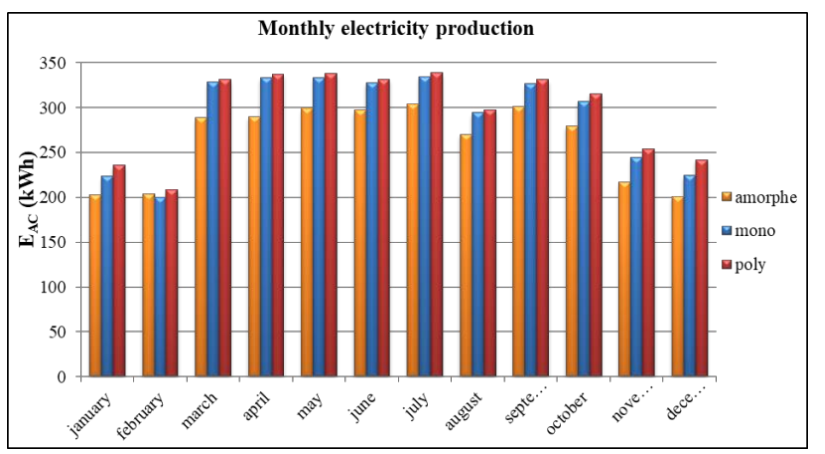

Fig 2. Average monthly AC electricity generated by the three PV systems.

It is observed that the average electricity output of the three technologies in August is low although the amount of irradiation is higher. When compared with the temperature curve, it can be seen that August is characterized by higher temperature values than the other months. Therefore, the high temperatures are not always synonymous with an increase in production by solar panels. The high luminosity in hot weather is certainly favorable for photovoltaic production, since the yield depends on the intensity of solar radiation. However, an increase in cell temperature leads to a decrease in panel efficiency. It is concluded that high temperatures do not favor the production of solar electricity. This explains the decrease in the energy 
produced by the three systems of the installation in the month of August.

\subsection{Conversion efficiency or system efficiency}

According to Figures 3, the conversion efficiency under actual operating conditions of the three technologies is close to that under standard test conditions in the winter months, but is lower in the summer months. The environmental conditions (solar irradiance, ambient air temperature, wind speed and direction) affect the conversion efficiency. The energy efficiency relative to irradiance and average monthly ambient air temperature for the three technologies was $8.43 \%, 13.67 \%$ and $13.03 \%$ respectively for a-Si, poly-Si and mono-Si PV panels.

Figure 3 shows that the efficiency increases as the ambient temperature decreases. The cell efficiency depends on the temperature: the higher the temperature increases, the lower the efficiency due to thermal agitation inside the material. The current increases slightly, but the voltage decreases more. This reduces the power and energy produced. In the month of February the efficiency decreases although the temperature drops, as well as the decrease in the amount of radiation reaching the PV panels, which leads to a low conversion of poly-Si and mono-Si systems. On the other hand a stabilization of the conversion efficiency for a-Si technology due to their characteristic of working with a lower amount of radiation.

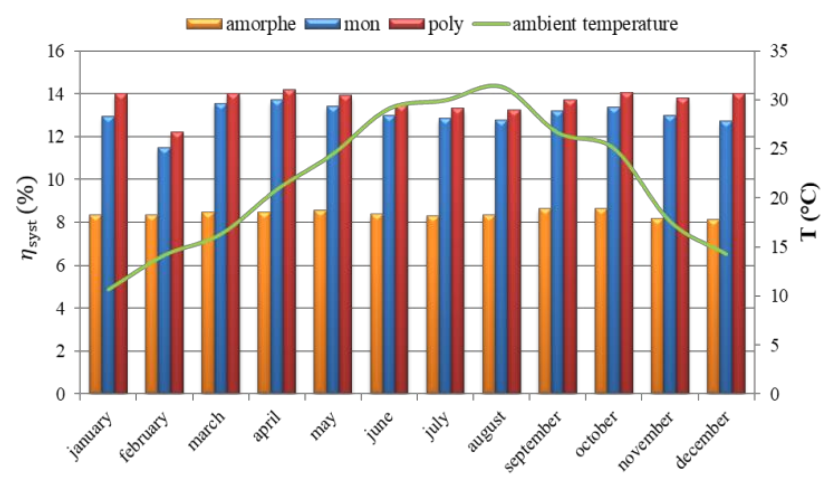

Fig 3. Monthly system efficiency and average monthly ambient temperature during the year 2017.

\subsection{Performance Ratio PR}

The performance ratio is a means of assessing the relative efficiency of a PV system. It is calculated using either equation 7 or 9 for 12 months for each technology as shown in Figure 4. The winter months have the highest PR values, with monthly average values reaching almost 0.91 in April for the poly-Si grid. Due to their lower temperature coefficient, the a-Si technology had lower PR values in the summer. In addition, the PR values were higher for poly-Si technology than for other PV systems [15].
The monthly average performance ratio ranged from: 0.82 in the winter to 0.88 in the summer for a-Si installation, 0.75 in the summer to 0.90 in the winter for mono-Si installation, 0.78 in the summer to 0.91 in the winter for poly-Si installation. Therefore, the average monthly performance index varies with the seasons. When the performance values are low in the summer for both mono-Si and poly-Si technologies. This drop in performance is explained by the increase in cell temperature, which causes a proportional drop in voltage.

Moreover, the increase in temperature does not only result in a drop in performance. Indeed a high temperature can also damage the cells. This damage is characterized by micro-breaks between the cells, possible corrosion of the conductive parts of the cells and the interconnections, not forgetting that the temperature itself contributes to the acceleration of the ageing of the cells. This has a direct effect on the performance of the PV panels.

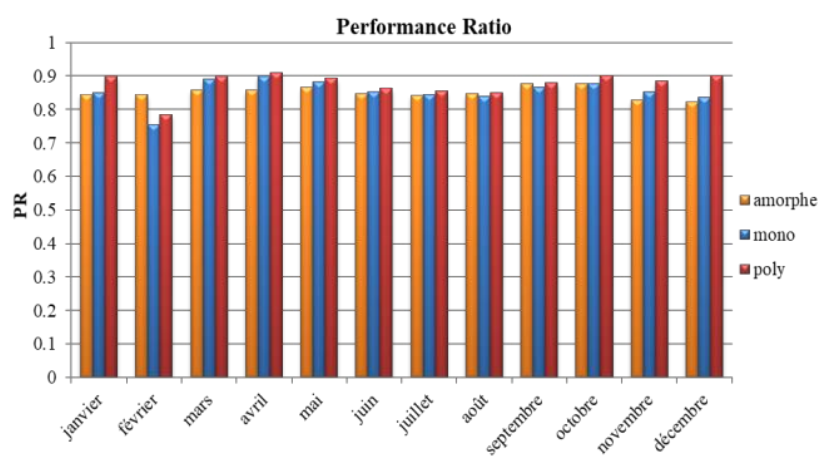

Fig 4. The monthly performance Ratio of the three PV technologies.

\subsection{Capacity factor}

The annual capacity factor of the PV system was calculated using equation 10, another indicator used to show how much PPS capacity occurs in a certain period of time [16]. It does not take into account environmental factors such as year-to-year irradiation variation and panel decommissioning or degradation. In other words [17], the $\mathrm{CF}$ is the ratio of the operating time under STC to the theoretical maximum operating time in a certain period of time. When considering the demand for electricity and meeting that demand on a continuous basis, a system or power plant is expected to have a CF of 100 per cent. 


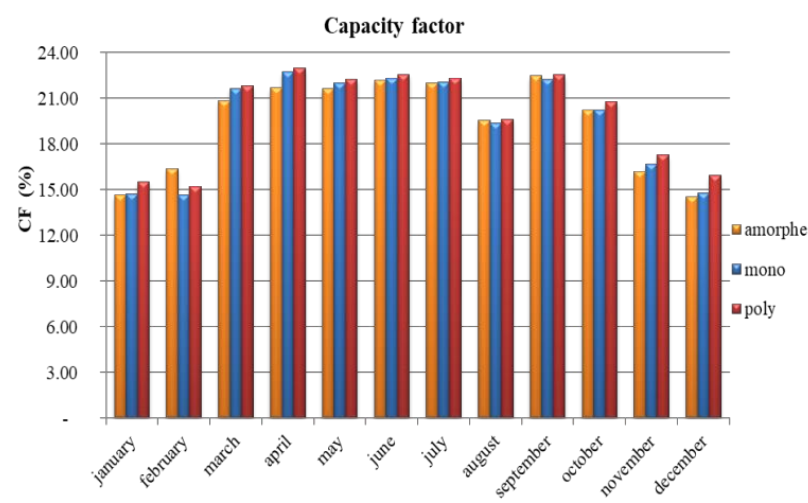

Fig 5. Monthly capacity factor of the three technologies.

The annual results for the system capacity factor show that the Poly-Si facility has a slightly higher value $(\mathrm{CF}=$ $19.92 \%)$ than the Mono-Si facility $(\mathrm{CF}=19.46 \%)$ and the a-Si facility (19.35\%). To summarize, the monthly average of the capacity factors CF ranged from :14.54\% to December as the minimum value and $22.47 \%$ to September as the maximum value for the a-Si plant. $14.63 \%$ to February as the minimum value and $22.71 \%$ to April as the maximum value for the Mono-Si plant. $15.21 \%$ to February as the minimum value and $22.97 \%$ to April as the maximum value for the Poly-Si plant.

\subsection{Comparative studies at different sites}

The data acquired in this study are useful for making comparisons with studies in other countries. Morocco is one of the most favorable places in Africa for the use of solar photovoltaic systems due to the high level of solar radiation. Although lignite is the main source of electricity generation in Morocco, solar photovoltaic systems can play a key role in the future in reshaping the energy supply system for a more sustainable, clean and reliable energy system.

\begin{tabular}{|c|c|c|c|c|c|}
\hline Location & $\begin{array}{l}\text { Type of } \\
\text { module }\end{array}$ & Yf (h/day) & RP & FC(\%) & $\begin{array}{c}\text { System } \\
\text { Efficiency(\%) }\end{array}$ \\
\hline \multirow{3}{*}{ Fez, Morocco } & $\mathrm{a}-\mathrm{Si}$ & 4,65 & 85,25 & 19,35 & 8,42 \\
\hline & Mono-Si & 4,68 & 86,70 & 19,46 & 13,03 \\
\hline & Poly-Si & 4,78 & 88,72 & 19,92 & 13,67 \\
\hline \multirow{3}{*}{$\begin{array}{l}\text { Casablanca, } \\
\text { Morocco }\end{array}$} & $\mathrm{a}-\mathrm{Si}$ & 4,33 & 73,1 & 18,05 & 7,21 \\
\hline & Mono-Si & 4,53 & 76,7 & 18,86 & 11,7 \\
\hline & $\begin{array}{l}\text { Poly-Si } \\
\end{array}$ & 4,47 & 75,6 & 18,64 & 11,4 \\
\hline \multirow{3}{*}{$\begin{array}{l}\text { Marrakesh, } \\
\text { Morocco }\end{array}$} & $\mathrm{a}-\mathrm{Si}$ & 4,21 & 70,9 & - & - \\
\hline & Mono-Si & 4,78 & 80,8 & - & - \\
\hline & Poly-Si & 4,69 & 83,8 & - & - \\
\hline \multirow{2}{*}{ Meknes, Morocco } & Mono-Si & 4.85 & 79.6 & 20,20 & 12.1 \\
\hline & $\begin{array}{l}\text { Poly-Si } \\
\end{array}$ & 4.98 & 81.7 & 20.52 & 12.3 \\
\hline \multirow{3}{*}{ Kocaeli, Turkey } & $\mathrm{a}-\mathrm{Si}$ & - & 89,76 & 17,78 & - \\
\hline & Mono-Si & - & 82,05 & 16,07 & - \\
\hline & $\begin{array}{l}\text { Poly-Si } \\
\end{array}$ & - & 83,8 & 15,75 & - \\
\hline \multirow{2}{*}{ Pristina, Kosovo } & Mono-Si & 3,64 & 84,0 & - & 12,78 \\
\hline & $\begin{array}{l}\text { Poly-Si } \\
\end{array}$ & 3,53 & 80,0 & - & 11,67 \\
\hline Dublin, Irlande & Mono-Si & 2,4 & 81,5 & - & 12,6 \\
\hline $\begin{array}{c}\text { Eastern Cape, South } \\
\text { Africa }\end{array}$ & Poly-Si & 4,9 & 84 & - & - \\
\hline $\begin{array}{l}\text { Khatkar-Kalan, } \\
\text { India }\end{array}$ & Poly-Si & 2,23 & 74 & - & 8,3 \\
\hline
\end{tabular}

Table 2. Performance of different grid-connected PV systems in different locations
The performance parameters evaluated for the Moroccan grid-connected photovoltaic systems installed in Fez are compared to the reported performance parameters of solar photovoltaic installations in various geographical locations and climatic conditions around the world, as shown in Table 2

It is clear that the performances obtained in the present study are well positioned among the other installations, notably because of the region's abundant solar potential. Comparison between the results of this study and other international studies has revealed that the average annual average daily final PV system yield of $4.65 \mathrm{kWh} / \mathrm{kWp} /$ day, $4.68 \mathrm{kWh} / \mathrm{kWp} /$ day and $4.78 \mathrm{kWh} / \mathrm{kWp} /$ day for a-Si, mono$\mathrm{Si}$ and poly-Si, respectively, is one of the highest annual yields. It is higher than those reported in Casablanca [5], Khatkar-Kalan, India [18], Pristina, Kosovo [19] and Northern Ireland [20]. But it is lower than the yields reported in South Africa [21] and most of Morocco Meknes [22] with values of $4.85 \mathrm{kWh} / \mathrm{kWp} /$ day and $4.98 \mathrm{kWh} / \mathrm{kWp} /$ day for mono-Si and poly-Si, respectively. And in the region of Marrakech [23] with values of $4.96 \mathrm{kWh} / \mathrm{kWp} /$ day and $4.78 \mathrm{kWh} / \mathrm{kWp} /$ day for a-Si and mono-Si, respectively. The measured annual performance rate of $85.25 \%, 86.70 \%$ and $88.72 \%$ for a-Si, mono-Si and poly-Si, respectively. This indicates the vast solar potential in the East Fez region suitable for solar power generation. The performance ratio measured at is higher than those reported elsewhere, with the exception of a grid-connected photovoltaic (a-Si) system in Kocaeli, Turkey [4] which gave a performance ratio of $89.76 \%$. The average annual capacity factor obtained from this study was $19.35 \%$, $19.46 \%$ and $19.92 \%$ for a-Si, mono-Si and poly-Si which is higher than the values of $17.78 \%, 16.07 \%$ and $15.75 \%$ reported in Kocaeli, Turkey. Two studies one reported by A. Allouhi et al [3] and the other by Amine Haibaoui and Bouchaib Hartiti, [1] showed a close agreement with our results, knowing that Casablanca, Meknes and Fez are characterized by similar arid and desert climatic conditions.

In general, the comparison of the three technologies installed in different Moroccan cities showed that the polySi PV technology is more efficient than the other two technologies in the regions of Fez, Meknes and Marrakech. On the other hand, the mono-Si technology is more efficient in Casablanca. It can also be concluded that the capacity factor values of our plant are almost high compared to that in Casablanca, but almost lower than the values given for Meknes. Therefore, we can conclude that Northern Morocco is generally a good region for the deployment of PV systems.

\section{CONCLUSION}

The performance of photovoltaic installations depends on climatic conditions such as temperature, irradiation. For this reason, their energy performance becomes an 
important subject of analysis for different locations of PV installations.

In this study, the overall performance of the three different PV technologies (a-Si, mono-Si and poly-Si) was examined. AC electricity from the inverter output, final yield, performance index and capacity factor were evaluated under the same weather conditions with the same orientation angle. Using 2017 measurements taken and a comparison had been presented between 2017 measurement and other data in the literation.

This study showed that the poly-Si module has the best performance under the Fez weather conditions. The overall annual efficiency of the PV system was found equal to $8.42 \%, 13.67 \%$ and $13.03 \%$ for a-Si, poly-Si and mono-Si installations respectively. The annual average daily efficiencies were found equal to $4.64 \mathrm{~h}, 4.78 \mathrm{~h}$ and $4.67 \mathrm{~h}$ for a-Si, poly-Si and mono-Si installations, respectively. The average performance index for a-Si, poly-Si and mono-Si panels was calculated to be $85.25 \%, 88.72 \%$ and $86.70 \%$, respectively. The annual capacity factor of the PV system was $19.35 \%$ for a-Si, $19.92 \%$ for poly-Si, and $19.46 \%$ for mono-Si, respectively. The systems studied in Fez have superior performance indicators to those of other installations in different locations in the world.

This work is part of the 'Propre.Ma' project which has been sponsored by IRESEN (Morocco) since February 2014. In the name of all the rest of the consortium members, authors would like to thank IRESEN Board and Scientific Committee for financing this through the INNO'PV Program as well as its General Manager, Badr IKKEN, and the rest of the staff for their daily efforts. Authors are grateful to all the other members of the 'Propre.Ma' consortium.

\section{References}

1. A. Haibaoui, B. Hartiti, A. Elamim, , Casablanca, Morocco.

2. A. El Fathi, A. Outzourhit A. Bennouna, (2017)

3. A. Allouhi, R. Saadani, T. Kousksou, R. Saidur, A. Jamil M. Rahmoune. (2016)

4. M.E.Başoğlu, A.Kazdaloğlu, T. Erfidan, Mehmet Z. Bilgin and Bekir Çakır, Kocaeli, Turquie (2015)

5. IEC 61724. (1998)

6. Aarich N, Erraissi N, Akhsassi M, Lhannaoui A, Mustapha $\mathrm{R}$, et al. IEEE Conference IRSEC (2014)

7. Nouredine Erraiss et al, Measurement 117 21-40 (2018)

8. S. Ferdoush, X. Li, Procedia Comput. Sci. 34 103-110, (2014)

9. IEC 61724. (1998)

10. https://thegrid.rexel.com/enus/energy efficiency/f/energy ef ficiency forum $/ 354 /$ what-is-the-capacity-factor-of-a-pv$\underline{\text { array }}$

11. M. Akhsassi. N. Aarich. R. Mustapha and Amin Bennouna. (2017)

12. M.Mabrouki and A. Bennouna., (2017)

13. NREL/CP-520-37358. (2005)

14. A. MohdKhalid, I. Mitra, W. Warmuth, V. Schacht, (2016)

15. SMA AG. http://chrosis.de/wpcontent/uploads/2012/12/PRvs-CUF-WP.pdf

16. https://en.wikipedia.org/wiki/Capacity factor

17. V. Sharma, S.S. Chandel, Pradesh, India, (2013)

18. V.Komoni, A. Gebremedhin, and N. Ibrahimi, Pristina,Kosovo,(2017)

19. L.M. Ayompe, A. Duffy, S.J. McCormack, M. Conlon, Ireland, 2010.

20. D. Okello, E.E. van Dyk, F.J. Vorster, South Africa, (2015).

21. A. Allouhi, R. Saadani, T. Kousksou, R. Saidur, A.Jamil and M. Rahmoune. (2016)

22. N.Aarich, A. Bennouna, N. Erraissi and R. Mustapha. (2016). 